\title{
RESEARCH
} Open Access

\section{The Antibacterial Activity of Acanthus ilicifolius L. n-Hexane Fraction}

\author{
Warsinah Warsinah ${ }^{1,},{ }^{*}$, Triyadi Hendra Wijaya ${ }^{1}$ and Nuraeni Ekowati ${ }^{2}$
}

\begin{abstract}
Background: Recently, the high prevalence of diarrhea caused by bacterial infection, the usage of antibiotics has increased. Antibiotic overuse might lead to several side effects and resistance, suggesting the development of an alternate antibacterial agent. A mangrove plant, Acanthus Illinois, contained triterpenoid, which has antibacterial properties.

Aim: This study aimed to evaluate the antibacterial effect of the Acanthus Illinois n-hexane fraction against Escherichia coliand Shigella dysenteriae.

Method: The Acanthus Illinois was fraction using n-Hexane, identification of secondary metabolite compound using GC-MS, and evaluation of antibacterial activity against Escherichia coliand Shigella dysenteriae under paper disc methods. This study was designed using a fully randomized design (CRD) with concentration of fraction $1 \%, 2 \%$, and $4 \%$. The GC-MS results were compared to the WILEY 9 library and analysis. Prism graph was used to measure inhibition zone of antibacterial activity.

Result: The $n$-hexane fraction yield is $3.3 \%$ and contains sesquiterpene compounds (trans (beta.)-caryophyllene, alpha humulene, naphthalene decahedron-4A-methyl), terpenoid alcohol (3,7,11,15-tetramethyl -2-hexadecane1-ol), and fatty acids (hexadecanoic acid methyl ester. Acanthus Illinois n-hexane fraction have antibacterial activity against Escherichia coli and Shigella dysenteriae in doses-dependent manner.

Conclusion: The n-hexane fraction of leaves Acanthus ilicifolius contains sesquiterpene, alcohol terpenoids, and fatty, and has antibacterial activity against Escherichia coli and Shigella dysenteriae
\end{abstract}

Keywords: Acanthus ilicifolius, Escherichia coli, Fraction, GC-MS, Shigella dysenteriae

\section{BACKGROUD}

Medicinal plants were rich in active compounds in diarrhea therapy. Data shows that diarrhea is the highest cause of child mortality. The number of children dying reaches $760,000^{1}$. The prevalence is $8.0 \%$ and children $11.0 \%$, these number continues to increase every year, increasing from 2013, which is only $7.0 \%$ and $2.4 \%{ }^{2}$. Bacteria such as Escherichia coli and Shigella dysenteriae cause diarrhea. The treatment uses antibiotics but side effects of allergies and resistance ${ }^{3}$. some plants were used of antibacterial such as Pyrrosia for itching, coughing ${ }^{4}$, dysentery ${ }^{4}$; Microsorum sp. as an antiulcer ${ }^{5}$; Drynaria quercifolia to treat diarrhea ${ }^{6}$, asthma, wound medicine and inflammation ${ }^{7,8}$. and antibacterial. In this study, plants of A illifolius were using. The selection of this plant was important for antibacterial. Jeruju (Acanthus ilicifolius) contains alkaloids, flavonoids, steroids, terpenoids ${ }^{9}$, with pharmacological activities such as analgesic, anti-inflammatory, antibacterial, and antioxidant.

\footnotetext{
*Correspondence: warsinah@unsoed.ac.id

${ }^{1}$ Departement of Pharmacy, Faculty of Health Science, University of Jenderal Soedirman, Purowkerto, Jawa Tengah, Indonesia

Full list of author information is available at the end of the article
} 
Acanthus ilicifolius empirically for therapy such as paralysis, asthma, ulcers, and wounds ${ }^{10}$, ethanol extract, and chloroform can inhibit Bacillus subtilis, Staphylococcus aureus, Pseudomonas aeruginosa, and Proteus vulgare bacteria ${ }^{11}$. Ethanol extracts effectively in Candida albicans, Aspergillus fumigatus, and Aspergillus nige ${ }^{11}$. Chloroform and methanol extracts in roots, stems, and leaves have potential on bacteria and fungi ${ }^{12,13}$. Gram-negative and positive potency ${ }^{14}$. Extracts of n-hexane contain triterpenoids ${ }^{15}$. Terpenoids have reduced the permeability of bacterial cell walls by damaging transmembrane proteins ${ }^{16}$. Inhibiting Methicillin Resistance Staphylococcus aureus (MRSA) ${ }^{17}$. Fraction, ethyl acetate, and n-butanol have inhibitory potential on Vibrio harveyi after incubation 12-48 hours ${ }^{18}$. Ethyl acetate extract can inhibit MDR (Multi-Drug Resistant); Klebsiella sp, Enterobacter 10, E. Coli, and Pseudomonas sp. Based on this information, it is necessary to explore the potential of compounds in Acanthus ilicifolius leaves as antibacterial recommended a traditional medicine for diarrhea.

\section{METHODS}

\section{Extraction and Fractionation Process}

The leaves of Acanthus ilicifolius were sorted, washed, chopped, and dried under sun light. Dried leaves made into powder. Five hundred grams of powder was extracted by the maceration method, using $96 \%$ ethanol with a ratio of dried leaves powder: ethanol (1:5) for $3 \times 24$ hours. The filtrate was filtered and evaporated using a rotary evaporator at $70^{\circ} \mathrm{C}$. Furthermore, the fractionated process a liquid-liquid partition using nHexane. n-Hexane fractions were concentrated for further tests.

\section{Phytochemicals of Acanthus ilicifolius}

Tannin analysis, Analysis used was the method reported ${ }^{19}$. Each Extract/fraction sample $(0.30 \mathrm{~g})$ was weighed into a test tube and boiled for 10 minutes in a water bath containing $30 \mathrm{~mL}$ of water. Filtration was carried out after boiling using number $42(125 \mathrm{~mm})$ Whatman filter paper. To $5 \mathrm{~mL}$ of the filtrate was added 3 drops of $0.1 \%$ ferric chloride. A brownish green or a blue black colouration showed positive test.

Saponin analysis. Methodology is as reported ${ }^{19}$. Distilled water $(30 \mathrm{~mL})$ was added to Extract/fraction sample $(0.30 \mathrm{~g})$ and boiled for 10 minutes in water bath and filtered using Whatman filter paper number 42 $(125 \mathrm{~mm})$. A mixture of distilled water $(5 \mathrm{~mL})$ and filtrate $(10 \mathrm{~mL})$ was agitated vigorously for a stable persistent froth. The formation of emulsion on addition of three drops of olive oil showed positive result.

Flavonoid analysis. The test for flavonoid adopted is as reported ${ }^{20}$.Each sample $(0.30 \mathrm{~g})$ weighed into a beaker was extracted with $30 \mathrm{~mL}$ of distilled water for 2 hours and filtered with Whatman filter paper number $42(125 \mathrm{~mm})$. To $10 \mathrm{~mL}$ of the aqueous filtrate of each wood extract was added $5 \mathrm{~mL}$ of $1.0 \mathrm{M}$ dilute ammonia solution followed by the addition of $5 \mathrm{~mL}$ of concentrated tetraoxosulphate (VI) acid. Appearance of yellow colouration which disappeared on standing shows the presence of flavonoids.

Alkaloid analysis. Test for flavonoid used is as reported ${ }^{21}$. Extraction of component from 2 grams of each wood powder sample was carried out using 5\% tetraoxosulphate (VI) acid (H2SO4) (20 mL) in $50 \%$ ethanol by boiling for 2 minutes and filtered through Whatman filter paper number $42(125 \mathrm{~mm})$. The filtrate was made alkaline using $5 \mathrm{~mL}$ of $28 \%$ ammonia solution (NH3) in a separating funnel. Equal volume of chloroform $(5 \mathrm{~mL})$ was used in further solution extraction in which chloroform solution was extracted with two $5 \mathrm{~mL}$ portions of $1.0 \mathrm{M}$ dilute tetraoxosulphate (VI) acid. This final acid extract was then used to carry out the following test: $0.5 \mathrm{~mL}$ of Dragendorff's reagent (Bismuth potassium iodide solution) was mixed with $2 \mathrm{~mL}$ of acid extract and precipitated orange colour infers the presence of alkaloid.

Steroid analysis. Analytical method used is according to ${ }^{19}$. Each sample $(0.30 \mathrm{~g})$ weighed into a beaker was mixed with $20 \mathrm{~mL}$ of ethanol; the component was extracted for 2 hours. To the ethanolic extract of each sample $(5 \mathrm{~mL})$ was added $2 \mathrm{~mL}$ acetic anhydride followed with $2 \mathrm{~cm} 3$ of concentrated tetraoxosulphate (VI) acid. 
Terpenoids analysis. Methodology is as reported ${ }^{19}$. Each wood powder sample $(0.30 \mathrm{~g})$ was weighed into a beaker and extracted with $30 \mathrm{~mL}$ and component extracted for 2 hours. A mixture of chloroform $(2 \mathrm{~mL})$ and concentrated tetraoxosulphate (VI) acid ( $3 \mathrm{~mL}$ ) was added to $5 \mathrm{~cm} 3$ of each extract to form a layer. The presence of a reddish brown colouration at the interface shows positive results for the presence of terpenoids.

\section{Profiling analysis of Acanthus ilicifolius n-Hexane Fraction}

A sample of $1 \mu \mathrm{L}$ inject of the GC-MS was operated using a glass column $25 \mathrm{~m}$ long, $0.25 \mathrm{~mm}$ in diameter, and $0.25 \mathrm{~mm}$ thick. $\mathrm{CP}-\mathrm{Sil} 5 \mathrm{CB}$ stationary phase with programmed oven temperature between 60 $270^{\circ} \mathrm{C}$ with a temperature rise rate of $10^{\circ} \mathrm{C} /$ minute, Helium carrier gas pressure of $12 \mathrm{kPa}$, the total rate of 30 $\mathrm{mL} / \mathrm{minute}$ and a split ratio of 1:50. This ionizing EI (Electron Impact) and ionization energy of $70 \mathrm{ev}$. The MS spectrum obtained is then matched with the reference standard mass spectrum in the tool library, then selected and identified the peak of the component that has a similarity index of more than or equal to $90 \%$.

\section{Antibacterial Activity}

The method used is Kirby Bauer disc diffusion with a completely randomized design. The samples tested were negative control (DMSO 10\%), positive control (ciprofloxacin), and fraction concentration treatment of $1 \%, 2 \%$, and $4 \%$. The treatment replicates three times. Parameters observed were the zone of inhibition. The present studies, Escherichia coli and Shigella dysenteriae suspensions on an agar medium under aseptic conditions. Disc paper is dipped into the sample and placed on the surface of the agar medium with tweezers. They incubated at $37^{\circ} \mathrm{C}$ for 24 hours. Then observe the zone of inhibition.

\section{Statistical analysis}

One way Analysis of Varian (Anova) was carried out to determine statistical significance and P value of less than 0.05 was considered as statistically significant. The phytocemistry analysis by description qualitative, GC-MS analysis of the n-hexane fraction was carried out in a qualitative description by the library. The antibacterial by graphad prism 8 .

\section{RESULTS}

Acanthus ilicifolius was determined to the Biology Faculty, Jenderal Soedirman University with certificate number 867/UN.23.02.8/TA.00.01/2019. The plants were dried and then extracted with ethanol and fractionated with $n$-hexane. The ethanol extract of yield of $19.6 \%$, and $n$-hexane fraction of $4.3 \%$. These results fraction yield a larger of previous research that is $2.2 \%{ }^{22}$.
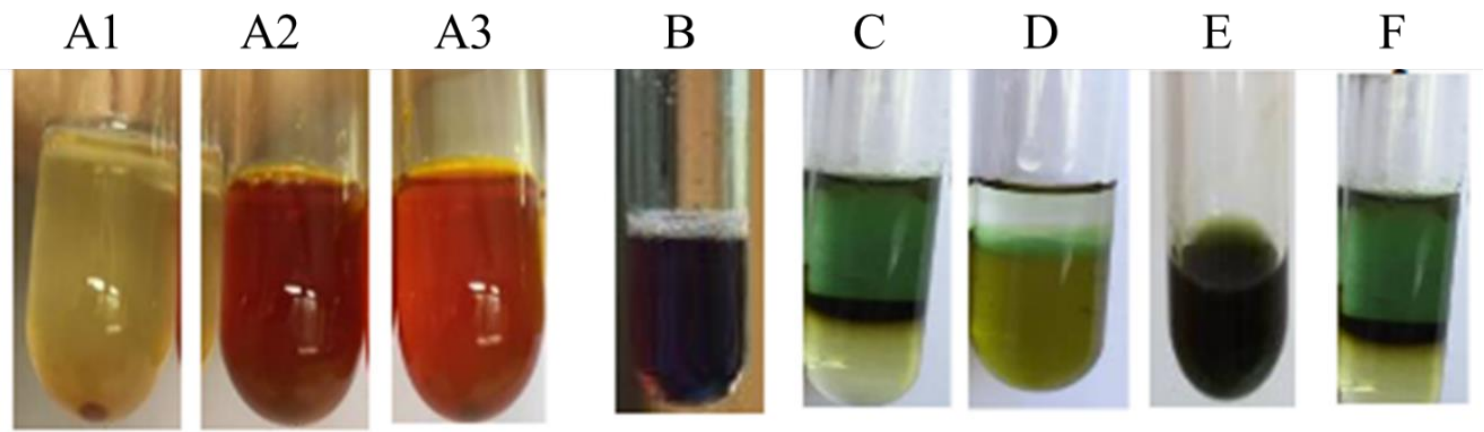

Figure 1. Phytochemical identification of Acanthus ilicifolius. (A1) Alkaloid test under mayer reagen. (A2) Alkaloid test under wagner reagen. (A3) Alkaloid test under dragendrof reagen.(B) Flavonoid test under $\mathrm{Mg}$ and $\mathrm{HCl}$. (C) Terpenoid test under Liebermann-Buchard reagen. (D) Steroid test with Liebermann-Buchard reagen. (E) Tanin-fenolic test with $\mathrm{FeCl}_{3}$. (F) Terpenoid test. 
The results of phytochemical screening on ethanol extracts contain flavonoid compounds with red due to colors, tannins (blue), terpenoids (green), alkaloids (orange to red), and steroids (yellow) (Tab 1, fig 1). The color is due to a chemical reaction ${ }^{23}$. Compounds have different characters from reactions for a class of compounds.

Table 1. Phytochemical screening of extract etanol and n-Hexane Fraction of Acanthus ilicifolius leaf

\begin{tabular}{clll}
\hline $\begin{array}{c}\text { Phytochemical } \\
\text { Compunds }\end{array}$ & Reagens & $\begin{array}{l}\text { Ethanolic } \\
\text { Extract }\end{array}$ & $\begin{array}{l}\text { N-Hexane } \\
\text { Fraction }\end{array}$ \\
Alkaloid & Mayer & + & - \\
& wagner & ++ & - \\
& dragendorf & ++ & - \\
Flavonoid & Mg powder+ HCl & ++ & - \\
Tannin & Ferri chloride & ++ & - \\
Terpenoid & Lieberman Burchard reagent & +++ & +++ \\
steroid & Lieberman Burchard reagent & + & - \\
\hline
\end{tabular}

$+++=$ appreciable amount (positive within 5 mins.); ++ = moderate amount (positive after 5 mins. but within 10 mins); $+=$ trace amount (positive after 10 mins. but within 15 mins); -+ negative

The results of the n-hexane fraction GC chromatogram analysis selected 15 peaks with high peaks, followed by MS analysis, then selected compounds with similarity index (SI) >90 and compared with the library on the tool (Figure 2 and Table 2).

Table 2. Compound Analysis on the mass spectrum of n-hexane fraction Acanthus ilicifolius

\begin{tabular}{|c|c|c|c|c|c|c|c|}
\hline No & $\begin{array}{l}\text { No } \\
\text { peaks }\end{array}$ & Compunds & $\begin{array}{l}\text { Simila } \\
\text { rity } \\
\text { index } \\
\text { (SI) }\end{array}$ & $\begin{array}{l}\text { Molekul } \\
\text { formula }\end{array}$ & $\begin{array}{l}\text { Retention } \\
\text { time }\end{array}$ & $\begin{array}{l}\text { Area } \\
(\%)\end{array}$ & Information \\
\hline 1 & 2. & $\begin{array}{l}\text { Trans (.Beta.)- } \\
\text { Caryophylenne }\end{array}$ & 95 & $\mathrm{C} 15 \mathrm{H}_{24}$ & 5.883 & 7.28 & Seskuiterpen \\
\hline 2 & 3. & $\begin{array}{l}\text { Trans(.Beta.)- } \\
\text { Caryophylenne }\end{array}$ & 96 & $\mathrm{C} 15 \mathrm{H}_{24}$ & 5.969 & 8.02 & Seskuiterpen \\
\hline 3 & 5. & $\begin{array}{l}\text { Alpha.Humulen } \\
\text { e }\end{array}$ & 92 & $\mathrm{C} 15 \mathrm{H} 24$ & 6.350 & 1.23 & Seskuiterpen \\
\hline 4 & 6. & $\begin{array}{l}\text { Naphtalene } \\
\text { decahydro -4 - } \\
\text { A-5-methyl }\end{array}$ & 93 & $\mathrm{C} 15 \mathrm{H} 24$ & 6.69 & 2.01 & Seskuiterpen \\
\hline 5 & 8. & 9-6Octadecene & 95 & $\mathrm{C} 18 \mathrm{H} 36$ & 7.554 & 1.34 & Alkena \\
\hline 6 & 9. & Pen 7 tadecane & 96 & $\mathrm{C} 15 \mathrm{H} 32$ & 7.604 & 1.87 & Alkana \\
\hline 7 & 10. & 9-Eic8osene & 96 & $\mathrm{C}_{2} \mathrm{OH} 40$ & 8.915 & 1.33 & Alkena \\
\hline 8 & 11. & Eicosa9ne & 94 & $\mathrm{C}_{2} \mathrm{OH} 42$ & 8.956 & 1.03 & Alkana \\
\hline 9 & 12 & $\begin{array}{l}\text { 6,10,14-10 } \\
\text { trimethyl-2- } \\
\text { Pentadecanone }\end{array}$ & 96 & $\mathrm{C} 18 \mathrm{H} 36 \mathrm{O}$ & 9.235 & 6.04 & alkanon \\
\hline 10 & 13. & $\begin{array}{l}\text { Hexadecanoic } \\
\text { acid,methyl ester }\end{array}$ & 97 & $\begin{array}{c}\mathrm{C} 17 \mathrm{H} 34 \mathrm{O} \\
2\end{array}$ & 9.732 & 14.63 & Alkana \\
\hline 11 & 14. & $\begin{array}{l}\text { Hexadecanoic } \\
\text { acid }\end{array}$ & 95 & $\mathrm{C} 16 \mathrm{H} 32$ & 9.941 & $\begin{array}{r}18.9 \\
5\end{array}$ & Alkana \\
\hline
\end{tabular}




\begin{tabular}{|c|c|c|c|c|c|c|c|}
\hline \multirow[b]{2}{*}{12} & \multicolumn{6}{|c|}{$\mathrm{O} 2$} & \multirow{3}{*}{$\begin{array}{c}\text { Terpenoid } \\
\text { Alkohol }\end{array}$} \\
\hline & 17. & $\begin{array}{l}3,7,11,15- \\
\text { tetramethyl- } \\
\text { 2- Hexadecen- } \\
\text { 1-ol }\end{array}$ & 94 & $\begin{array}{c}\mathrm{C}_{2} \mathrm{OH} 40 \\
\mathrm{O}\end{array}$ & 10.845 & 4.83 & \\
\hline 13 & 18. & $\begin{array}{l}\text { Octadecanoic } \\
\text { acid,methyl } \\
\text { ester } \\
\text { (CAS) }\end{array}$ & 91 & $\begin{array}{c}\mathrm{C} 19 \mathrm{H} 38 \\
\mathrm{O} 2\end{array}$ & 10.897 & 2.66 & \\
\hline 14 & 19. & $\begin{array}{l}9,12- \\
\text { Octadecadienoic } \\
\text { acid (CAS) }\end{array}$ & 94 & $\begin{array}{c}\mathrm{C} 18 \mathrm{H} 32 \\
\mathrm{O} 2\end{array}$ & 10.968 & 15.41 & alkana \\
\hline 15 & 20. & $\begin{array}{l}\text { 9- } \\
\text { Octadecenoic } \\
\text { acid }\end{array}$ & 91 & $\begin{array}{c}\mathrm{C} 18 \mathrm{H} 34 \\
\mathrm{O}_{2}\end{array}$ & 11.095 & 2.05 & alkana \\
\hline
\end{tabular}

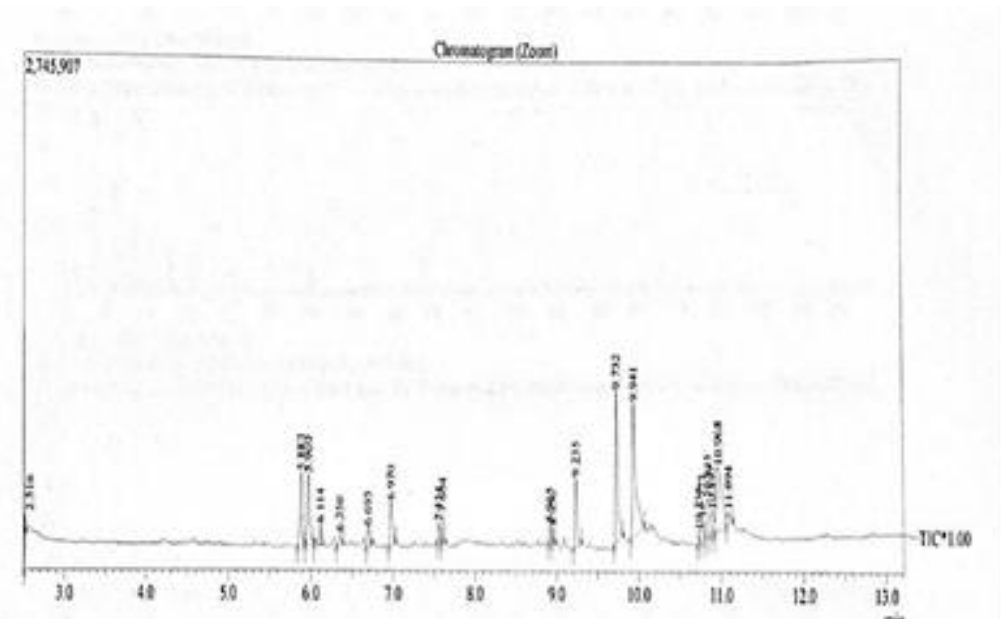

Figure 2. Profile of chromatogram on n-hexane fraction on gas chromatography.

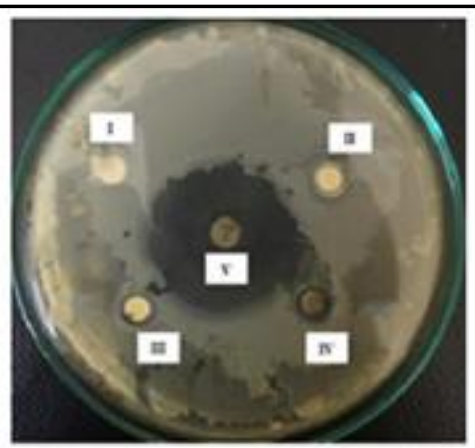

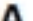

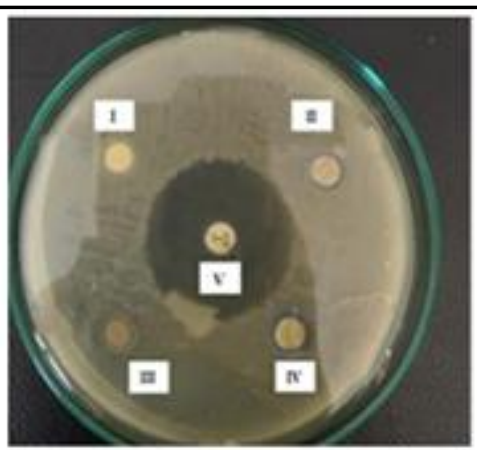

R

Figure 3. Antibacterial Activity of n-Hexane Fraction of Leaf A. illicifolius. (A) Inhibition zone of E.coli, (B) Inhibition zone of $S$. dysenteriae. I= DMSO 10\%, II= $1 \%$ n-hexane fraction, III $=2 \%$ n-hexane fraction, $\mathrm{IV}=4 \% \mathrm{~N}$-hexane fraction, $\mathrm{V}=$ ciprofloxacin $5 \mu \mathrm{g}$ 


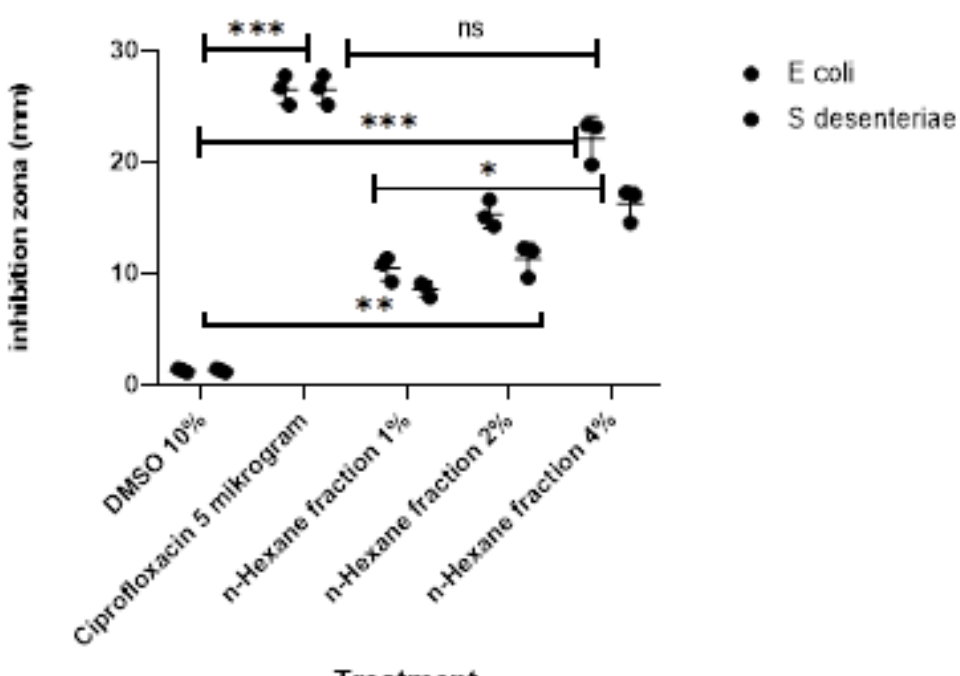

Figure 4. Antibacterial activity with inhibition zone in the treatment of $\mathrm{n}$-hexane fraction, *** significantly $(\mathrm{p}>0.05), * *$ significantly $(\mathrm{P}>0.05) . *$ Significant, NS $=$ no Significant

The treatment in the antibacterial activity test was a negative control (DMSO 10\%), positive control of ciprofloxacin, and three concentrations of the n-hexane fraction, namely $1 \%, 2 \%$, and $4 \%$ ), the present study. the fraction treatment could inhibit E coli and shigella bacteria (Figure 3 and Table 1).

\section{DISCUSSION}

The plant used was A. ilifolius leaf, which is from the Segara Anakan lagoon of Cilacap. The fraction yield of 4.3 percent, this result is greater than the previous researcher's 2.2\% (suryati, 2018). GC-MS analysis showed 15 compounds with a similarity index (SI)>90. These 15 compounds include terpenoids, fatty acids, alkanes, alkenes, and ketone compounds. The sesquiterpenes (terpenoid) on trans -beta-caryophyllene, alphahumulene, Naphthalene decahydro-4 -A-5 methyl, which is strong in oral effect ${ }^{24,25}$. (Trans (beta)caryophyllene (H15C24) has a base peak of $\mathrm{m} / \mathrm{e} 41$ and a molecular ion peak of $\mathrm{m} / \mathrm{e} 204$. Fragmentation is $\mathrm{m} / \mathrm{e}$ 204 with cleavage of $\mathrm{CH} 3(\mathrm{M}+-15)$ into fragment with a peak $\mathrm{m} / \mathrm{e}$ of 189 . Becomes with cleavage $\mathrm{CH} 2=$ $\mathrm{CH} 2(\mathrm{M}+-18)$ into fragment peak $\mathrm{m} / \mathrm{z} 161$, and leavage $\mathrm{CH} 2(\mathrm{M}+-14)$ into fragment peak m/e 147. Becomes with the cleavage of $\mathrm{CH} 2(\mathrm{M}+-14), \mathrm{CH}(\mathrm{M}+-13), \mathrm{CH} 3(\mathrm{M}+-15), \mathrm{C} 2 \mathrm{H} 3(\mathrm{M}+-27), \mathrm{C} 3 \mathrm{H} 2(\mathrm{M}+-38)$ and tCH2 $(\mathrm{M}+-14)$ into a fragment ion with $\mathrm{m} / \mathrm{z}$ peak of 41 .

Fragmentation of m/e 204 with cleavage of $\mathrm{CH} 3(\mathrm{M}+-15)$ into fragment ion m/e 189. $\mathrm{CH} 2=\mathrm{CH} 2(\mathrm{M}+$ -18 ) becomes a fragment ion with a peak $\mathrm{m} / \mathrm{e}$ of 161 . Then cleavage of $\mathrm{CH} 2(\mathrm{M}+-14)$ becomes a fragment ion with a peak of $\mathrm{m} / \mathrm{e}$ of 147 . Fragmentation of $\mathrm{m} / \mathrm{e} 147$ with termination of $\mathrm{C} 2 \mathrm{H} 3(\mathrm{M}+-27)$. Hexadecanoic acid $(\mathrm{C} 16 \mathrm{H} 32 \mathrm{O} 2)$ with a molecular ion peak of $\mathrm{m} / \mathrm{e} 256$. There are three fragmentation pathways of hexadecanoic acid m/e 256. First, H3C-CH2 (M+ -29), H3C-CH2-CH2 (M+ -43), H2C= CH2-(CH2)11CH3 becomes fragment ion with a peak of $\mathrm{m} / \mathrm{e} 60$. In the second path, the fragment of $\mathrm{m} / \mathrm{e} 227$ occurs four times $\mathrm{H} 2 \mathrm{C}=\mathrm{H} 2 \mathrm{C}$ cleavage. The $\mathrm{H} 3 \mathrm{C}-\mathrm{CH}=\mathrm{CH} 2(\mathrm{M}+-42)$ becomes a fragment ion with a peak of $\mathrm{m} / \mathrm{e} 73$. The third pattern occurs Fragmentation at m/e 213 with $\mathrm{H} 2 \mathrm{C}=\mathrm{H} 2 \mathrm{C}$ breaking three times and at fragment m/e 129 breaking $\mathrm{CO} 2(\mathrm{M}+-$ 44) and H3C-CH2-CH3 (M+ -44) to fragment ion m/e 41. Fragmentation at m/e 60 with $\mathrm{OH}$ cleavage (M+ - 
17) becomes fragment ion with peak $\mathrm{m} / \mathrm{e} 43$.

The n-hexane fraction of jeruju leaves contain terpenoids and fatty acids with antibacterial activity by transmembrane protein and reducing the permeability of bacterial cell walls ${ }^{16}$ and preventing the function of ATP synthase ${ }^{26}$. sesquiterpenes (terpenoids) are hydrophobic. The compound is causing protein denaturation, cell membrane lysis ${ }^{27}$. Ethyl acetate extract from Grewia Pubescens has a compound 3,7,11,15-tetramethyl-2hexadecane-1-ol ${ }^{28}$. These compounds inhibited S. aureus, E. coli, B. subtilis, and P. aeruginosa with high activity at $25-200 \mathrm{mg} / \mathrm{ml}$.

\section{CONCLUSION}

The transplantation of MSCs ameliorated LF by reducing SGPT and SGOT concentration.

The n-hexane fraction of jeruju leaves (Acanthus ilicifolius L) contains 3,7,11,15-tetramethyl-2-hexadecane1-ol, and fatty acids have antibacterial activity. All concentrations of the tested fractions had activities, and the highest concentration of $4 \%$ activity was in both E. coli and S. dysenteriae with inhibition zones of $11.67 \mathrm{~mm}$ and $10.33 \mathrm{~mm}$.

\section{ACKNOWLEDGEMENT}

Thank you to the Rector of the University of Jenderal Soedirman through the chairman of LPPM Unsoed of the funded this research.

\section{CONFLICT OF INTEREST}

We declare that we have no conflict of interest.

\section{AUTHORS' CONTRIBUTION}

THW analyzes and interprets the GC-MS results. NE tested the activity of the extract against E coli and S dysenteriae bacteria. WA was performing the extraction, fractionation, phytochemical screening, and antibacterial analysis using GraphPad Prism 8, and the major contributor in the writing of the manuscript. All authors read and approved the final manuscript.

\section{FUNDING}

None

\section{AUTHOR DETAILS}

${ }^{1}$ Departement of Pharmacy, Faculty of Health Science, University of Jenderal Soedirman, Purowkerto, Jawa Tengah, Indonesia

${ }^{2}$ Departement of Biology, Faculty of Biology, University of Jenderal Soedirman, Purowkerto, Jawa Tengah, Indonesia

\section{REFERENCES}

1. World Health Organization. Diarrhoeal Diseasee. https://www.who.int/mediacentre/factshseets/fs330/en. Published online 2013.

2. Kemenkes. Riset Kesehatan Dasar 2018. Ris Kesehat Dasar. Published online 2018.

3. Utami ER. Antibiotika, Resistensi dan Rasionalitas Terapi. El Hayah. 2011;1(4):191-198.

4. Arif, M.Z., Zainuddin, N.A.S.N, Zakaria, I.S., , Wahab, W.N.A.W.A, \& Sul'ain MD. Phytochemical Screening and Toxicological Evaluation of Pyrrosia piloselloides Extracts. Int Med J. 2018;25(3):177180.

5. Ho R., Teai T., Bianchini JP., Lafont R. \& RP. Ferns: From Traditional Uses to Pharmaceutical $54 \mid \mathrm{P}$ a g e 
Development, Chemical Identification of Active Principles. In: Kumar A., Fernández H., Revilla M. (eds) Working with Ferns. Springer,. Published online 2010.

6. Ahmed, F.A., Rahman, A. \& Mubassara S. Phytochemical composition, antioxidant activity and cytotoxicity of Blumea lacera Linn. from two different habitats. Jahangirnagar Univ J Biol Sci. 2016;3:37.

7. Cruz, R.Y.D., Ang, A.M.G., Doblas, G.Z., Librando, I.L., Porquis, H.C., Batoctoy, B.C.L.S., Cabresos, C.C., Jacalan, D.R.Y., \& Amoroso VB. Phytochemical Screening, Antioxidant and Anti-inflammatory Activities of the Three Fern (Polypodiaceae) Species in Bukidnon, Philippines. Bull Environ Pharmacol Life Sci. 2017;6(3):28-33.

8. Ghorpade, P.N., Thakar, S., Dongare, M and Kale M. Phytochemical Analysis Of Four Cheilanthes Species From Northern Western Ghats Of India. Res J Pharm Biol Chem Sci. 2019;1:92-100.

9. Constabel, P.C., Yoshida, K. and Walker V. Diverse Ecological Roles of Plant Tannins: Plant Defense and Beyond. In Recent Advances in Polyphenol Research. First. John Wiley \& Sons; 2014.

10. Mani, Senthil Kumar KT., Puia, Z., Samantha, SK., Barik, R., Dutta, A., Gorain B. The Gastroprotective Role of Acanthus ilicifolius : A Study to Unravel The Underlying Mechanism of Anti Ulcer Activity. Sci Pharm. 2012;80:701-707.

11. Bose, S. \& Bose A. Antimicrobial Activity of Acanthus ilicifolius L. Indian J Pharm Sci. 2008;70(6):821823.

12. Khajure, Pradeep V. \& Rathod J. Antimicrobial Activity of Extracts of Acanthus ilicifolius Extracted from The Mangroves of Karwar Coast Karnataka. Recent Res Sci Technol. 2010;2(6):98-99.

13. M. Ahmad . A, Wudil AM. Phytochemical screening and toxicological studies of aqueous stem bark extract of Anogeissus leiocarpus in rats. Asian J Sci Res. 2013;6(4):781-788.

14. Ganesh, S \& Venilla J. Screening for Antimicrobial Activity in Acanthus ilicifolius. Arch Appl Sci Res. 2010;2:311-315.

15. Muharni, Elfita H. Isolasi Triterpenoid dari Akar Tumbuhan Jeruju (Acanthus ilicifolius Linn). J Penelit Sains. 2013;11:8-13.

16. Rachmawati, F., Nuria, M. S. Uji Aktivitas Antibakteri Fraksi Kloroform Ekstrak Etanol Pegagan (Centella asiatica (L) Urb) serta Identifikasi Senyawa Aktifnya. J Ilmu Farm Farm Klin. Published online 2011.

17. Govindasamy, C. \& Arulpriya M. Antimicrobial Activity of Acanthus ilicifolius : Skin Infection Pathogens. Asian Pacific J Trop Dis. 2013;3(3):180-183.

18. Saptiani, G., Prayitno, SB., Anggoro S. Potensi Antibakteri Ekstrak Daun Jeruju (Acanthus ilicifolius) terhadap Vibrio harveyi secara In Vitro. J Kedokt Hewan. 2013;7(1).

19. C. M. Ejikeme, C. S. Ezeonu and ANE. Determination of physical and phytochemical constituents of some tropical timbers indigenous to Niger Delta Area of Nigeria. Eur Sci J. 2014;10(18):247-270.

20. Sofowara. Medicinal Plants and Traditional Medicine in Africa. Spectrum Books; 1993.

21. H. Hikino, Y. Kiso, H.Wagner and MF. Antihepatotoxic actions of flavonolignans from Silybum marianum fruits. Planta Med. 1994;50(3):248-250.

22. Suryati, S., Husni, E., Astuti, W., \& Ranura N. Karakterisasi dan Uji Sitotoksik Daun Jeruju (Acanthus illicifolius). J Sains Farm Klin. 2018;5(3):207-211.

23. Barthi M. Studies on phytochemical analysis and screening for active compounds in some ferns of Ranchi and Latehar district. Int J Acad Res Dev. 2018;3(1):33-44.

24. Santos, L. S., Fernandes Alves, C. C., Borges Estevam, E. B., Gomes Martins, C. H., de Souza Silva, T., Rodrigues Esperandim, V., \& Dantas Miranda ML. Chemical Composition, In Vitro Trypanocidal and Antibacterial Activities of The Essential Oil from The Dried Leaves of Eugenia dysenterica DC from Brazil. J Essent Oil Bear Plants. 2019;22(2):347-355.

25. Hossain, M.A., Al-Raqmi, K.A.S., Al-Mijizy, Z.H., Weli, A.M., \& Al-Riyami Q. Study of total phenol, flavonoids contents and phytochemical screening of various leaves crude extracts of locally grown Thymus vulgaris. Asian Pac J Trop Biomed. 2013;3(9):705-710.

26. Padmini, E. A., Valarmathi, A., and Rani M. Comparative Analysis of Chemical Composition and Antibacterial Activities of Mentha spicata and Camellia sinennsis. Asian J Exp Biol Sci. 2010;1(4):772- 
781.

27. Alexander DK. Efek Ekstrak Temulawak (Curcuma xanthorriza Roxb) terhadap Resisten Staphylococcus aureus (MRSA). Majority. 2015;4(8):177-184.

28. Hamid, A. A., Oguntoye, S. O., Alli, S. O., Akomolafe, G. A., Aderinto, A., Otitigbe, A., \& Aminu RO. Chemical Composition, Antimicrobial and Free Radical Scavenging Activities of Grewia pubescens. Chem Int. 2016;2(4):254-261. 